\title{
Amount of Air Ions Depending on Indoor Plant Activity
}

\author{
Natālija Siṇicina, Andris Skromulis, Andris Martinovs \\ Rezeknes Augstskola, Faculty of Engineering, \\ Address: Atbrivosanas aleja 76, Rezekne, LV-4601, Latvia
}

\begin{abstract}
Literature sources and earlier researches state that plants may be able to produce a variety of air ions, including negative light ions. In this article, the regularity of influence of plants on the number of ions in the room is being proved, basing on a series of experiments performed with the following plants: Spathiphyllum, Scindapsus, Strobilanthes, Chlorophytum and Pinus mugo. It was concluded that plants, in general, are able to stabilize the indoor ion concentration and reduce its fluctuations. The plants help to increase the concentrations of negative ions and decrease the concentration of positive ones, however the optimal and "healthy" ion concentration was not reached. Plants without artificial illumination work more as ion reducers, not producers.
\end{abstract}

Keywords: air ions, plants, microclimate.

\section{INTRODUCTION}

Under normal circumstances (temperature $0^{\circ} \mathrm{C}$, pressure $760 \mathrm{mmHg}$ ), one cubic meter of air contains $2,5.10^{25}$ molecules. They are in a constant thermal motion, moving randomly and colliding continuously with each other. Very soon, the light atomic or molecular ion attracts conglomeration of molecules and becomes intermediate ion with a much greater mass and lower mobility [1]. When settling on microparticles, aerosols, dust, etc., these ions are converted into heavy and super-heavy air ions having a large mass and even smaller mobility. These are not ions any more but rather charged aerosols whose concentration depends entirely on the purity of the ionized air [2].

Small air ions are constantly being produced in nature by radioactive components of the soil, by cosmic rays, by the shearing of water droplets, etc. In clean air they can exist for several minutes, but their numbers are depleted by air pollutants, by stray electrical fields and by the mere presence of occupants in a room. Almost always there is a fluctuating equilibrium between ion formation and ion loss [3]. Under normal conditions there is a small difference between the positive and negative ions on the ground floor level in the atmosphere. Any disturbance of ion balance has direct impact on living organisms [4].

The presence of negative air ions (NAI) in the inhaled air is essential for normal functioning of human and animal organisms [5]. Scientific research indicates that the air within homes and other public or office buildings can be more seriously polluted than the outdoor air. Public concern about the effects of indoor air pollution on health has resulted in expanded research of the topic [6]. Some countries have already elaborated legal framework for air ion concentration in work rooms. On 16 June 2003, sanitary and epidemiological rules and regulations "Hygienic Requirements for the Air-Ion Level of Industrial and Public Facilities SanPin 2.2.4 1294-03" [7] (Санитарно-эпидемиологические правила и нормативы "Гигиенические требования к аэроионному составу воздуха производственных и общественных помещений СанПин 2.2.4 1294-03") entered into force in the Russian Federation. According to these Requirements, optimal concentration of light negative ions amounts to $3000-$ 5000 , while concentration of positive ions should be half as much. However in most cases, the concentration of favorable light, negative air ions indoors does not exceed few dozens, while the concentration of harmful positive ions is growing rapidly, especially if there are people, TVs, computer monitors and similar devices in the room [8].

Ions are particles of the air that have either positive or negative electrical charge. In natural environment they are usually produced to maintain a healthy ratio, but in artificial environment of air conditioning, electrical equipment, fluorescent lighting and even synthetic clothing the balance can be seriously affected [9]. NAI concentration decreases considerably or even falls to zero in the polluted air of cities, in closed and air-conditioned rooms, near operating household and office equipment. The absence of NAI in the air may cause health disorders, whereas inhaling the NAI-enriched air improves health and human comfort [10]. Besides, practical field testing reveals that the somnolence, apathy, 
headaches, etc. ascribed to the "dead" air in enclosed spaces can be conquered effectively by supplying moderate concentrations of negative ions [3]. Air ions may be healing or may harmfully affect human health. This effect depends on ion concentration in the air and on proportions of positive and negative ions. These proportions are characterized by unipolarity coefficient

$$
K=\frac{n^{+}}{n^{-}}
$$

where $\mathrm{n}^{+}$and $\mathrm{n}^{-}$mean concentration of positive and negative cluster ions.

Interaction of air ions and plants may be expressed in various ways, and nowadays this topic is being studied. Artificially controlled environment of air ions in greenhouses is experimentally used to harvest more vegetables [11] because ionized air particles contribute to a faster exchange of substances in plants [12]. However, numerous cases show that air ions in combination with strong anthropogenic atmospheric pollution can also enhance negative effects on plants. Air ions of different classes, products of radon gas decay and charged aerosol particles which are spread in the atmosphere are considered to be factors causing damages of tree foliage and trunk [13].

Plants are reported to be able to produce various air ions, including NAI, under normal conditions [14]. Most plants emit different types of volatile organic compounds (Bio VOCs) and even micro-amount of Bio VOCs has a great impact on formation processes of cluster ions [15]. This effect is reinforced when volatile compounds are emitted from the plant in ionic form, e.g., Bio VOCs emitted from the needles of conifers are ionized because of charges accumulated in the sharp tips of the needles. Ions of volatile compounds are very good condensation nuclei in the atmosphere that contribute to further formation of mist and clouds. Thus, coniferous forests can even affect the global climate [16]. To a certain extent, most of the plants are air ion generators. Intensity of such generation depends on the daily intensity cycle of metabolic process in these plants [17].

Indoor plants improve quality of the air. Some plants effectively clean the air from organic contaminants [18], while other plants reduce the amount of micro-organisms in the air because of phytoncide effect. Plants produce oxygen and absorb carbon dioxide [19,20]. Many plants humidify intensely the air of the room. As elements of phytodesign, houseplants have a positive impact on the psycho-emotional state of the occupants. As a consequence of people staying indoors, the indoor air is saturated with anthropogenic organic, microbial and aerosol pollution to a greater extent than the natural air. The indoor air contains less small oxygen ions than the natural air [21].

Light-absorbing pigments in photo-organisms capture photons of certain colors and reflect other colors. The energy of a photon is transferred through a long chain of molecules to the reaction center, which splits water to produce high-energy electrons for biochemical reactions. The process of photosynthesis (especially the light phase) is directly related to changes in the difference of potentials on the thylakoid membranes of chloroplasts [22,23].

In chloroplasts, thioredoxin is restored by taking electrons from the recovered molecules of ferredoxin. The recovered thioredoxin is oxidized, giving, in its turn, the electrons to the molecule of enzyme. Thus, during the transition from darkness to light, when the circuit of electron transportation begins in the chloroplasts and the recovery of the molecules of ferredoxin takes place, several enzymes are being activated [18].

Productivity of the photosynthesis of plants is determined by two major parameters: the total surface of leaves (assimilative surface) and the intensity of photosynthetic processes per unit of leaf surface [24]. To make normal growth of plants possible, the light is needed. Almost all greenhouse use partial supplementary lighting of plants with a help of lamps [25].

As any process involving photochemical reactions, photosynthesis is also characterized by the lowest amount of light needed to begin the process. Starting from this point, the dependence of photosynthesis on the intensity of the light can be showed with a help of logarithmic curve. Initially, increase of the light intensity leads to a proportional growth of photosynthesis (area of the maximum effect). Within this level of lighting, the speed of photosynthesis is limited by the light. With further raise of the light intensity, photosynthesis continues to increase, but the process is slower (area of weakened effect). Finally, the light intensity increases, but photosynthesis remains the same (area of light - plateau) (Fig.1) [26].

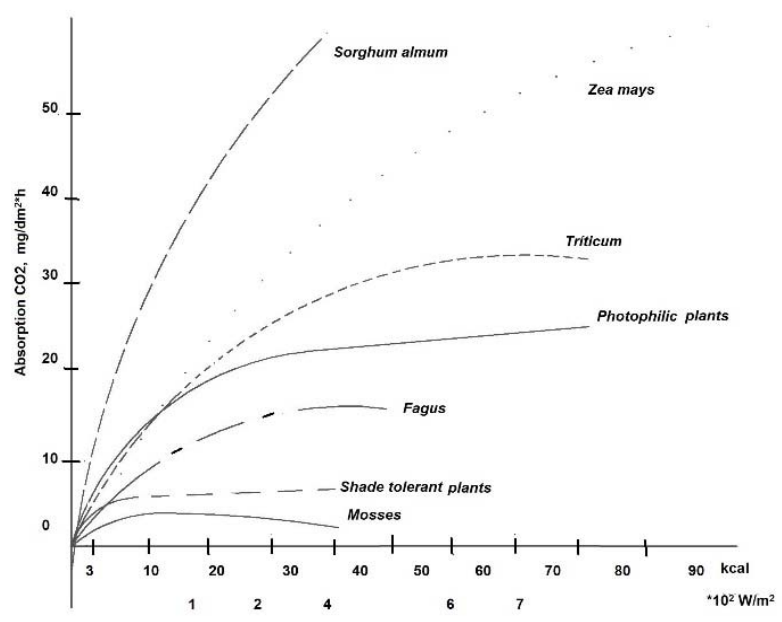

Fig. 1. Photophilic and shade tolerant plants light saturation (the plateau) 


\section{MATERIALS AND METHODS}

We used the same plant species [26] and found similar species-dependent differences in the ability to generate NAI. The data presented in this paper prove that the capacity of plants to generate NAI differs. The aim of the experiments was to find the species with the most expressed capability to generate NAI.

In order to perform this study, several plants were selected which, by their nature and taking into account the impact of external factors, can affect the air ion concentration indoors. Therefore, plants with the following characteristics were chosen: large area of leaves, leaves with a pointed tip and hair shaft; developed transpiration function (as a result of transpiration a lot of water is vaporized from plants), dust particle absorption, expressed phytoncide features.

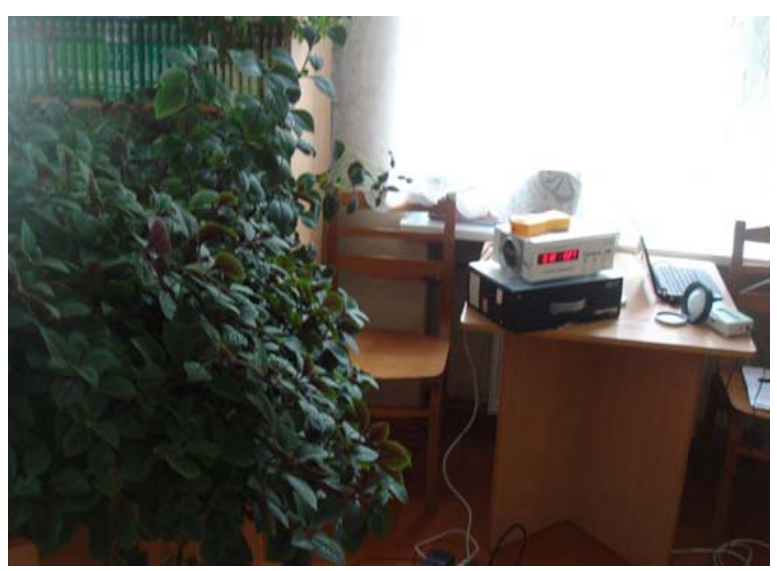

Fig. 2. Scheme of Measuring Devices and Groups of Indoor Plant. Phyto-Module of Strobilanthes.

\subsection{Five Plant Phyto-Module}

Phyto-module of five plants (Fig.2) (a complex of specially selected plants for environmental improvements) was created basing on the following five plants (Table 1.). The size of the phyto-module is approximately $800 \times 800 \times 800 \mathrm{~mm}$.

Air ion concentration was measured with the portable bipolar air ion counter "Sapfir-3m". This device provides simultaneous measuring of positive and negative air ions with minimum resolution of 10 ions per $1 \mathrm{~cm}^{3}$. The device measures air ion concentration in the air (mobility $\mathrm{k} \geq 0.4 \mathrm{~cm}^{2} \mathrm{~V}^{-1} \mathrm{~s}^{-1}$ ). This mobility interval is close to the class of cluster ions [27]. During the measurements, air ions, according to their polarities, are channelized to positive or negative aspiration collector in aspiration chamber and, after coming into contact with this collector, the ions are discharged. Afterwards, the charge is sent to amplifiers and then the impulses are counted and displayed. The device counts the charges of air ions, therefore if an ion has more than one charge, it is counted as several ions.

TABLE 1.

\section{PLANTS VARIETIES}

\begin{tabular}{|c|c|c|c|}
\hline Latin name & Properties [27] & $\begin{array}{l}\text { Requirements for } \\
\text { lightning }\end{array}$ & $\begin{array}{l}\text { Size, } \\
H / D, c m\end{array}$ \\
\hline Spathiphyllum & $\begin{array}{l}\text { Reduces the } \\
\text { amount of benzene } \\
\text { and } \\
\text { trichloroethylene, } \\
\text { high efficiency of } \\
\text { phytoncides }\end{array}$ & $\begin{array}{l}\text { Bright, scattered } \\
\text { in spring }\end{array}$ & $35 / 40$ \\
\hline Scindapsus & $\begin{array}{l}\text { Reduces the } \\
\text { amount of benzene } \\
\text { and formaldehyde, } \\
\text { average efficiency } \\
\text { of phytoncides }\end{array}$ & Indirect, bright & $40 / 50$ \\
\hline
\end{tabular}

\begin{tabular}{|c|c|c|c|}
\hline Strobilanthes & $\begin{array}{l}\text { Reduces the } \\
\text { amount of } \\
\text { formaldehyde } \\
\text { average efficiency } \\
\text { of phytoncides }\end{array}$ & Indirect, bright & $35 / 45$ \\
\hline Chlorophytum & $\begin{array}{l}\text { Reduces the } \\
\text { amount of benzene } \\
\text { and formaldehyde, } \\
\text { high efficiency of } \\
\text { phytoncides }\end{array}$ & Indirect, bright & $35 / 45$ \\
\hline Pinus mugo & $\begin{array}{l}\text { Reduces the } \\
\text { amount of benzene } \\
\text { and formaldehyde, } \\
\text { high efficiency of } \\
\text { phytoncides }\end{array}$ & Indirect, bright & $50 / 55$ \\
\hline
\end{tabular}

Indoor climate parameters were determined using the multi-meter "Easy Sense Q". Systematic measurement error of this device for temperature is \pm $0.3{ }^{\circ} \mathrm{C}$, whereas error for relative humidity is $\pm 5 \%$. Error for lighting is not specified. The total amount of radioactive $\alpha, \beta$ and $\gamma$ radiation was measured in $\mu \mathrm{Sv} \cdot \mathrm{h}^{-1}$ with the portable device "Gamma-Scout" with systematic measurement error less than $5 \%$. For all devices, the average value of each measurement point was 10 minutes. Each time the measuring devices were placed in a distance of approximately $40 \mathrm{~cm}$ from the phyto-module, at a height of $120 \mathrm{~cm}$ from the floor.

The measurements were carried out in automatic mode for each photo-module individually. During the first 48 hours, microclimate parameters of the room were measured without any plants. Afterwards, phytomodules of each plant species were measured, the measuring process was identical for each plant.

The experiment was taking place in a room of 12 $\mathrm{m}^{2}$ and $36 \mathrm{~m}^{3}$. The room has one window towards East. The room is located on the first floor, it is closed and without forced ventilation. During the measurements, people were present in the room only once a day to switch on the devices, to turn on online mode for measuring or to change phyto-modules. 
When carrying out measurements in natural (noncontrolled) lightening, difference in light intensity was a disturbing factor, because the experiment was carried out within a period of several days (some of them were sunny, while other days were cloudy), therefore the level of lightening in the room changed. As a result, it was decided to carry out an experiment when micro-climate parameters were measured under circumstances of controlled lightening.

\subsection{Controlled Light}

The experiment was carried out in the same room. The window was closed with an opaque tissue not to let the light in. The phyto -module was created of five plant species used in the previous experiment as well. The total number of plants: 30 items. The total surface of the phyto-module amounted to $2 \mathrm{~m}^{2}$. Arrangement of plants and devices remained the same (Fig.2). Measuring of micro-climate parameters was carried out using the same instruments: in the room with and without plants for 24 hours without lighting (in the dark), 24 hours with fixed lighting (1000 1x). During this experiment, gas concentration in the air was not measured. Meteorological data on ultraviolet radiation provided by Rucava Station were also taken into account [28]. The experiment was carried out repeatedly.

\subsection{Phyto-Module of Pinus Mugo}

For the needs of the experiment, a phyto-module was created of the coniferous plant Pinus mugo. The experiment was carried out in the above mentioned room without lighting (in the dark). The mode of experiment remained the same.

\section{RESULTS AND DISCUSSION}

After carrying out experiments with five plants, it is not possible to select one particular species that would be the best generator of negative ions. On the first day of the experiment, the best results were shown by Pinus Mugo, but later its capacity to generate ions decreased. The overall conclusion is that the capacity of plants to produce air ions is fluctuating and requires a much longer study period than a few days. Supposedly, air ion balance indoors is also affected by other unintentional and uncontrolled factors.

The experimental data (see Fig.3) show that the number of positive air ions in the given rooms is higher than the number of negative air ions: $20-29 \%$ (without houseplants) and 23-68\% (with houseplants). Maximum / minimum concentration of positive air ions: $159 \mathrm{~cm}^{3} / 76 \mathrm{~cm}^{-3}$ (without houseplants) and $180 \mathrm{~cm}^{3} / 30 \mathrm{~cm}^{3}$ (with houseplants). Maximum / minimum concentration of negative air ions: $110 \mathrm{~cm}^{3} / 54 \mathrm{~cm}^{3}$ (without houseplants) and $115 \mathrm{~cm}^{-}$
$3 / 33 \mathrm{~cm}^{3}$ (with houseplants). These data reveal that, basing on the air ion concentration and unipolarity coefficient, the room used for the experiments is not recommended for human health (if not ventilated). The room has very low concentration of positive and negative air ions and inadequate unipolarity coefficient, because, basing on the SanPin 2.2.4 129403, minimal admissible concentration of positive air ions is $400 \mathrm{~cm}^{3}$, negative air ions $600 \mathrm{~cm}^{-3}$, admissible values of unipolarity coefficient $0.4<\mathrm{K}<1.0$. During the day, the room temperature increases and relative humidity decreases because of the sunlight. The measured average ambient temperature in the room without plants is about $30 \mathrm{C}$ higher than in the room with plants. The average humidity is up to $6 \%$ higher in the room with plants than in the room without plants. It means that plants increase the air humidity (the water is evaporated through leaf pores).

\subsection{Five Plant Phyto-Module}

During the research of phyto-modules of five plants, analysis of data provided by the air ion counter showed that at night the total number of ions is 5 $15 \%$ less than in the daytime.

A significant increase in negative ions was observed during the study of the phyto-module of conifer Pinus Mugo, i.e. Mountain pine. This increase amounted to $5 \%$ if compared to a room without plants and to $30 \%$ if compared to the indexes obtained during the work with other phyto-modules. Low concentrations of air ions were recorded when working with the phytomodule of Hlorofitum, although this plant is considered to have a positive effect on the environment and to reduce the air pollution. Decrease in the number of air ions was observed on the second day of the study in the presence of plants in the room.

A common trend - without controlled lighting, plants stabilize fluctuations of air ion concentrations in the room. They become predictable, depending on the natural day lighting modes, besides the amplitude of fluctuations is smaller.

At the same time, in a room without plants the total number of ions is $15-20 \%$ less at night than during the day. The total number of ions in an empty room without plants is $30-35 \%$ more than in a room with plants (Fig.3).

\subsection{Controlled-light}

The experiment showed that, regardless of whether there is artificially created dimming or constant artificial lighting, there is a tendency of reduction of the number of air ions during the night and the increase of their number in the daytime. In a room with lighting and plants, the number of ions was $15 \%$ higher than in a room with plants and without light. (Fig.4.,5.) 


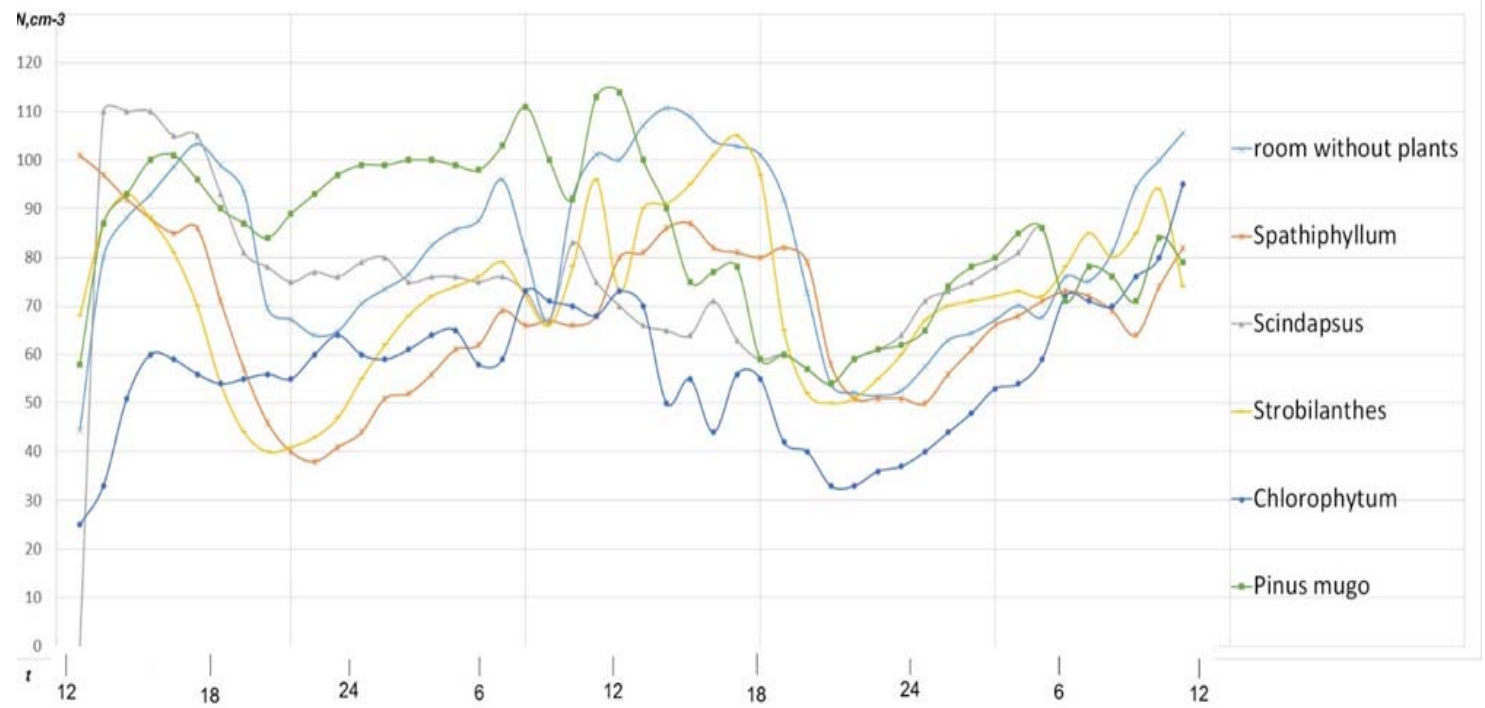

Fig.3. Concentration of negative ions in the air with five photo-modules and in the room without plants.
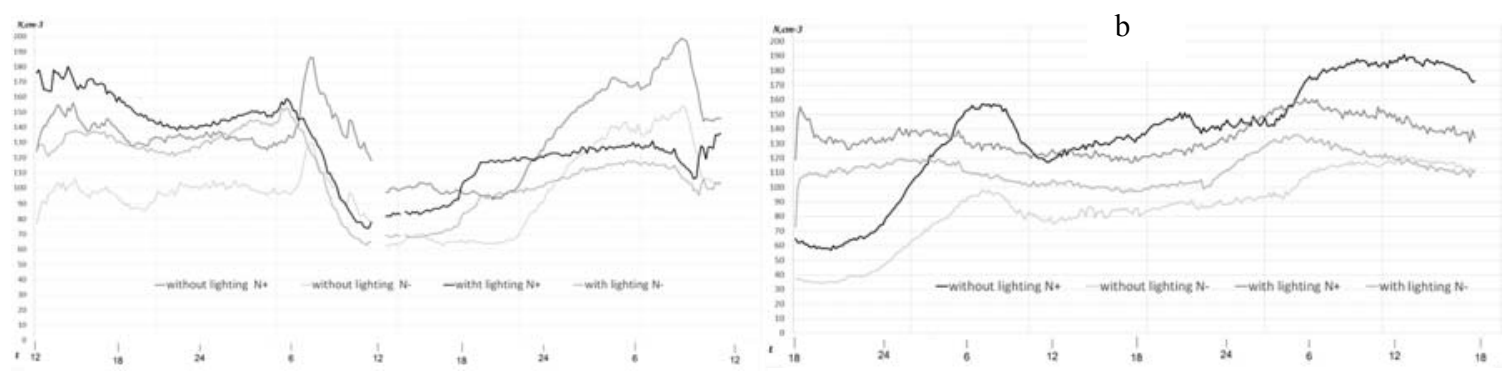

Fig.4. Concentration of negative and nositive ions in the air with plants in the room with and without lighting.

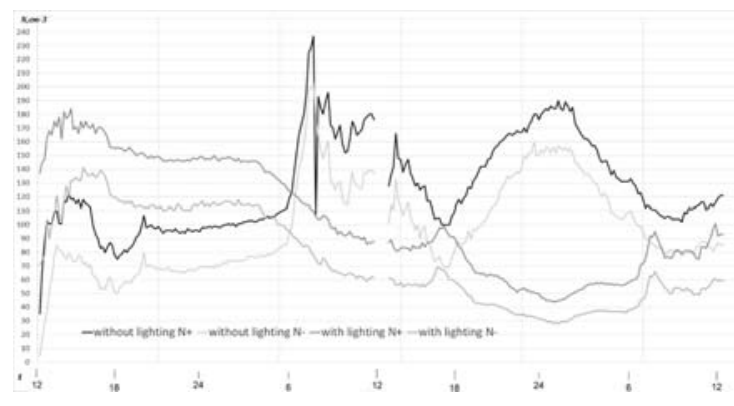

b

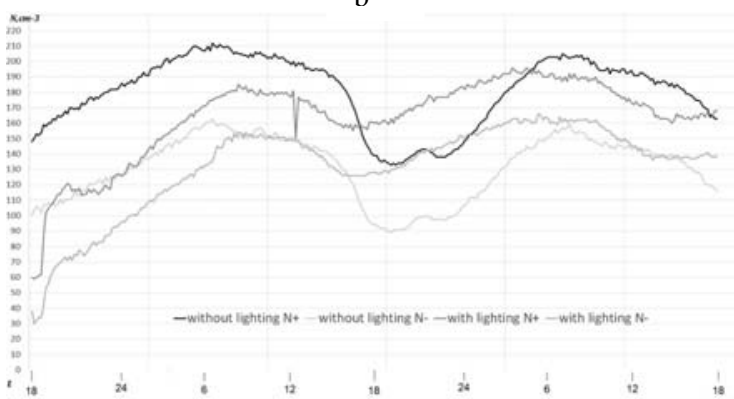

Fig.5. Concentration of negative and positive ions in the room without plants in the room with and without lighting. 
Thus, it can be concluded that the light needed for photosynthesis raises the capacity of plants to generate air ions. Without lighting, metabolic processes in plants are slower and less active, so the plants serve as air ion absorbers rather than producers because of the large total surface of their foliage.

TABLE 2.

AVERAGE IONS CONCENTRATION

\begin{tabular}{c|c|c|c|c|}
\hline \multirow{2}{*}{$\begin{array}{c}\text { Conditions/ } \\
\text { Parameters }\end{array}$} & \multicolumn{2}{|c|}{ In the dark } & \multicolumn{2}{c|}{$\begin{array}{c}\text { With } \\
\text { controlled } \\
\text { lighting }\end{array}$} \\
\cline { 2 - 5 } & $\begin{array}{c}\text { Without } \\
\text { plants }\end{array}$ & $\begin{array}{c}\text { With } \\
\text { plants }\end{array}$ & $\begin{array}{c}\text { Without } \\
\text { plants }\end{array}$ & $\begin{array}{l}\text { With } \\
\text { plants }\end{array}$ \\
\hline $\mathrm{N}^{-}$ & 115 & 92 & 103 & 111 \\
\hline $\mathrm{N}^{+}$ & 155 & 136 & 134 & 131 \\
\hline $\mathrm{N}^{\text {(total) }}$ & 270 & 228 & 237 & 242 \\
\hline $\mathrm{K}$ & 1.35 & 1.47 & 1.30 & 1.18 \\
\hline & & & & \\
\hline
\end{tabular}

In a dark room with plants, not only the total air ion concentration is significantly lower if compared to an artificially lit room; the value of the unipolarity coefficient $\mathrm{K}$ is also lower, which is almost in distinguishable from the $\mathrm{K}$ value in a room without plants. It means that if there is no light, plants in the room are not useful because their impact on air ion concentration is minimum.

Analyzing the results obtained at constant artificial light, it can be concluded that the presence of plants in a room increases the concentration of negative air ions and slightly reduces the concentration of positive ions, thus stabilising the $\mathrm{K}$ value closer to zero. However, in our experiment this effect did not appear to be sufficient to reach the amount of air ions favorable for human health with a help of plants and to ensure the $\mathrm{K}$ $<0$, which would be recommended from the medical point of view. (Table 2).

It should be noted that even in the room without lighting and without plants, there were still daily fluctuations of the air ion concentrations, which apparently do not depend only on the sunlight and the presence of plants, but it is caused by other air ion producing and loss mechanisms. Constant artificial lighting slightly reduced these fluctuations by increasing the concentration of ions at night, and slightly decreasing it during the day.

\subsection{Phyto-Module of Pinus Mugo}

Experiments with Pinus Mugo, as probably one of the plant species that significantly affect the air ion microclimate indoors, deserve a lot of attention in further studies (Fig.7). Analyzing our first study in a room with shielded windows, it can be concluded that this plant species is great in dealing with the rapid and often chaotic air ion fluctuations caused by various factors. Pinus Mugo decreased fluctuations of air ion concentrations to almost constant level that almost does not depend on external factors. It only remains to find an opportunity to stimulate metabolic processed in these plants with the help of adequate lighting and other techniques, in order to achieve the required level of air ion concentration indoors (Fig.6).

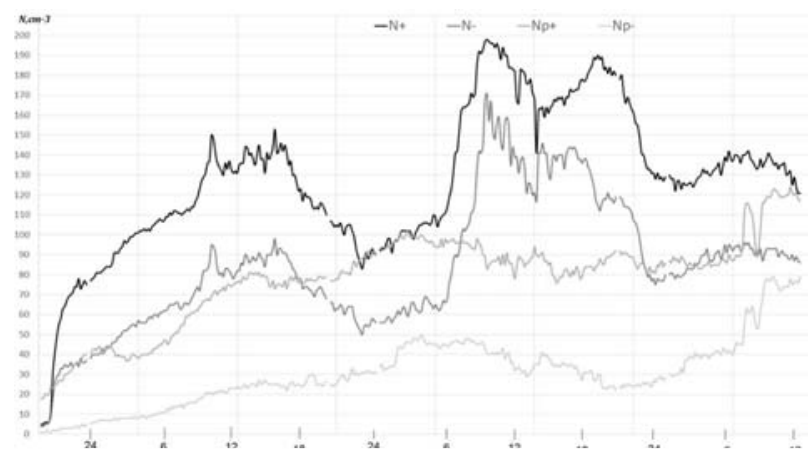

Fig.6. Concentration of negative and positive ions in the air with Pinus Mugo in comparison with the room without plants.

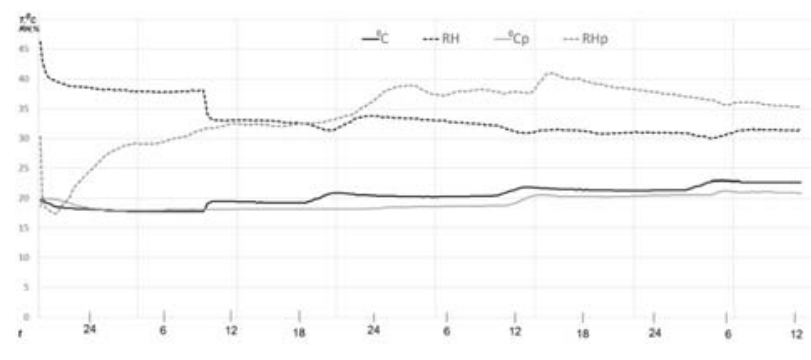

Fig.7. Measurements of temperature and relative humidity in the room with Pinus Mugo in comparison with the room without plants.

\section{CONCLUSION}

Our experiments have revealed that plants can work as ion generators only in controlled or uncontrolled lighting due to increased photosynthesis and metabolism. In the dark, plants are rather ion absorbers due to the large surface of their leafs. Presence of plants in the room can significantly stabilize uncontrolled fluctuations of ion concentration, however the necessary level of ionization was not reached. Conifers, e.g. Pinus Mugo, might be the best ion producers, however further continuous experiments are needed to identify the plant species that would the best in ion production.

\section{REFERENCES}

[1] Аэроионизация в народном хозяйстве [Elektronic resource] /http://bershoz.com/aerofikacia-v-narodnomhoziaystve/aerofikacia-v-narodnom-hoziaystve $42 . \mathrm{html}$ (15.06.2014)

[2] Поляков В. Физика аэроионизации. Журнал “Радио Наука и Техника" 3 номер, Москва [Elektronic resource] http://www.chipinfo.ru/literature/radio/200203/p36-38.html (15.06.2014) 
[3] Dr. A. P. Krueger „The biological effects of air ions” International Journal of Biometeorology (1985), Vol. 29, no. 3, pp. 205-206

[4] "The effect of high concentration of negative ions in the air on the chlorophyll content in plant leaves." Institute of Physics, Center of Experimental Physics, Lab. Multidisc. Res., Zemun, Yugoslavia; 2 FON, Belgrade University, Belgrade, Yugoslavia

[5] Charry, J.M. and Kvet, R., Air Ions: Physical and Bio- logical Aspects, Boca Raton: CRC, 1984, Biological effects of small air ions: A review of findings and methods. Environmental Research, Vol. 34, Issue 2, pp. 351-389.

[6] Handbook of Environmental Engineering, Volume 2: Advanced Air and Noise Pollution Control Edited by: L. K. Wang, N. C. Pereira and Y.-T. Hung $(\mathcal{C}$ The Humana Press, Inc., Totowa, NJ

[7] Санитарно-эпидемиологические правила и нормативы "Гигиенические требования к аэроионному составу воздуха производственных и общественных помещений СанПин 2.2.4 1294-03")

[8] "Дисплейная болезнь" и "Люстра Чижевского" [Elektronic resource]

http://filiaev.narod.ru/medizina/medizina10.htm(15.06.2014)

[9] Ventilation and the Air Ion Effect in the Indoor Building Environments: Impact on Human Health and WellbeingS.A. Abdul-Wahab (ed.), Sick Building Syndrome, DOI 10.1007/978-3-642-17919-8_28, C Springer-Verlag Berlin Heidelberg 2011

[10] Kondrashova, M.N., Grigorenko, E.V., Tikhonov, A.N., Sirota, T.V., Teplov, A.V., Stavrovskaya, I.G., Kosya- kova, N.I., and Tikhonov, V.P., The Primary Physico- Chemical Mechanism for the Benefical Biological/Med- ical Effects of Negative Air Ions, IEEE Trans. Plasma Sci., 2000, vol. 28, pp. 230-237.

[11] Kellogg E. W. Air Ions: their Possible Biological Significance and Effects. Electromagnetic Biology and Medicine, 1984, Vol. 3, No.1-2, pp. 119-136.

[12] Скипетров В. П., Еникеев О. Л., Зорькина А. В., Иничина В. И., Мартынова В. В. (1995) Аэроионы и жизнь. Саранск: Изд-во Мордов. университета, 1995, 96 с.

[13] Tammet H. and Kimmel V. (1998) Electrostatic deposition of radon daughter clusters on the trees. J. Aerosol Sci. 29, pp. 473-S474

[14] Nemeryuk, G.E., Salt Migration into Atmosphere during Transpiration, Fiziol. Rast. (Moscow), 1970, vol. 17, pp. 673-679 (Sov. Plant Physiol., Engl. Transl.).

[15] Hoffmann T., Bandur R., Marggraf U., Linscheid M. (1998) Molecular composition of organic aerosols formed in the $\alpha$ pinene/O3 reaction: Implications for new particle formation processes. Journal of Geophysical Research: Atmospheres (1984-2012) Vol. 103, Issue D19, pp. 25569-25578.

[16] Kulmala M., Hämeri K., Aalto P.P., Mäkelä J. M., Pirjola L., Douglas Nilsson E., Buzorius G., Rannik Ü., Dal Maso M., Seidl W., Hoffman T., Janson R., Hannson H.-C., Viisanen Y., Laaksonen A., O'Dowd C. D. Overview of the international project on biogenic aerosol formation in the boreal forest (BIOFOR). Tellus B, 2000, Vol. 53, Issue 4, pp 324343.

[17] Wang J., Li S. H. Changes in negative air ions concentration under different light intensities and develop-ment of a model to relate light intensity to directional change. Journal of Environmental Management, 2009, Vol. 90, Issue 8, pp. 2746-2754.

[18] М.П. Федоров, Г.Л. Спичкин, К.В.Воробьев, О.Ю.Кудрявцев. "Комнатные растения против органических загрязнителей”. Экология и жизнь, № 11(84), 2008, pp. $80 . \quad$ - $85 . \quad$ [Elektronic resource]/http://www.ecolife.ru/arhiv/flash/84\%28112008\%29.html (15.07.2014)

[19] Г.Л.Спичкин, К.В.Воробьев, М.П.ФеО.В. Войцеховскаядоров, О.Ю.Кудрявцев. Влияние антропогенных аэроионных воздействий на фотосинтез Tradescantia fluminensis Vell. Санкт-Петербургский государственный политехнический Университет Ботанический Институт им. В. Л. Комарова РАН [Elektron-ic resource]/OOO «НПО «Фитотехнология» http://phyteco.ru/o_nas/publikatsii (01.07.2014)

[20] Цыбуля Н.В., Фершалова Т.Д. Фитонцидные растения в интерьере (оздоровление воздушной среды с помощью растений). - Новосибирск: Новосибирское книжное издво, 2000, pp. 112. lpp.

[21] Федоров М.П., Воробьев К.В., Замараева В.С., Спичкин Г.Л. «Аэроионы для здоровья». Экология и жизнь, № $8(81), 2008, \quad$ pp. 78. - 82.[ Elektronic resource]/http://www.ecolife.ru/arhiv/flash/81\%2882008\%29.html- (19.09.2014)

[22] Duddington C.L. Evolution in plant design. London. 1969,pp. 304.[Elektronic resource]/ http://catalogue.nla.gov.au/Record/1852814.pdf (10.03.2013)

[23] Николас Д. Биоэнергетика. Введение в хемиосмотическую теорию. М., Мир, 1985, рp. 146. [Elektronic resour-

ce]/http://cyberpirate.me/bittorrent/viewtopic.php?t=3770865 (20.09.2014)

[25] Мухамедов Г.А. Эффективность природных цеолитов в экологически ориентированном земледелии степного зауралья Башкортостана. 2009, pp. 2.

[26] О гидропонном выращивании растений [Elektronic resource] http://www.ponics.ru/2009/06/light/(15.06.2014)

[27] Влияние условий на интенсивность процесса фотосинтеза [Elektronic resource] http://fizrast.ru/fotosintez/intensivnost.html (15.06.2014)

[28] Hõrrak U., Salm J., Tammet H. Statistical characterization of air ion mobility spectra at Tahkuse Observatory: classification of air ions. J. Geophys. Res. Atmos., No. 105, 2000, pp. 9291-9302.

[29] Faktisko meteorolog̣isko novērojumu digitalizēta datu bāze [Elektronic resource] http://meteo.lv/meteorologija-datumeklesana/?nid=461 $(15.06 .2014)$

[30] Zemes magnetosfêras un jonosfēras monitorings [Elektronic resource] www.citadapasaule.com (15.06.2014) 